\title{
A dialética como discurso do método
}

Ricardo Musse

G eorg Lukács formou-se no âmago da cultura burguesa, em estreita convivência com os principais intelectuais húngaros e alemães. Após o fim da Primeira Guerra M undial, relativamente consagrado e reconhecido por seus pares - entre eles T homas M ann, Georg Simmel e M ax Weber -, para surpresa de todos aderiu ao marxismo. A pesar do pendor radicalmente anticapitalista de seus textos de juventude, a passagem da filosofia idealista e da crítica cultural ao marxismo desobedece qualquer lógica imanente. Em seu primeiro livro propriamente marxista, H i tória e consciência declasse, de 1923, ele próprio chama a atenção para as circunstâncias históricas, ao justificar sua "conversão" pela superioridade da explicação marxista do presente, em especial da tríade "guerra, crise e revolução".

H istória e consciência de classe pouco alude a essa súbita transmutação. Embora uma série de referências à cultura burguesa encontre-se disseminada ao longo do livro, Lukács parece mais interessado em posicionar-se no interior da tradição marxista. 0 "Prefácio", por exemplo, ressalta como propósito da obra determinar o ponto de vista do "marxismo ortodoxo", por meio da compreensão e do esclarecimento da "essência do método de Marx".

A defesa da "ortodoxia" adquire um sentido preciso no cenário de então, pautado pelo confronto entre concepções e práticas políticas bastante diferenciadas, um contraponto que ameaça instaurar a fragmentação e a 
dispersão na linhagem do marxismo. Ela delimita, de antemão, o campo em que Lukács situa-se, isto é, o movimento comunista agrupado na recém-fundada Terceira Internacional, uma cisão no interior do marxismo que se inicia com divergências, no início do século XX, acerca do caráter da sociedade capitalista e do sentido da Revolução Russa de 1905, mas que se cristalizou apenas depois de 4 de agosto de 1914 e da revolução bolchevique, em outubro de 1917.

Lênin e Rosa Luxemburgo já haviam estabelecido, no âmbito político, os princípios dessa corrente, em especial sua diferença perante as alas da social-democracia com as quais se convivia, antes da Primeira Guerra, de forma mais ou menos pacífica no interior da Segunda Internacional. $\mathrm{Na}$ medida em que resume o propósito de seu livro, de forma genérica, como a "resolução de determinadas questões teóricas do movimento revolucionário", Lukács apenas se propõe a complementar um corpus constituído a partir de críticas que adotaram como alvo prioritário as concepções de Karl Kautsky - segundo essa tendência, a melhor encarnação do espírito prevalecente no partido social-democrata alemão (cf. Luxemburgo, 1974; Lênin, 1979).

N o que concerne à discussão política propriamente dita, Lukács pouco se afasta de Rosa Luxemburgo e de Lênin, ora aplainando as divergências entre eles, ora se orientando pendularmente em direções opostas. Sua ambição teórica, no entanto, vai além. Procura determinar a essência do mé todo de Rosa e de Lênin. 0 que, convenhamos, não seria demasiado, pois se parte da premissa de que esses esforços intelectuais e práticos derivam em linha direta de uma adequada compreensão da metodologia de $M$ arx. $M$ as por que tanta ênfase no método, por que se concentrar em pressupostos e conseqüências metodológicas de textos que prescindem, de forma deliberada, do tom auto-reflexivo?

H isória e consciência de classe não se propõe apenas a resgatar a relevância da estrutura teórica subjacente aos textos para apresentar, em outro registro, a trajetória política de Rosa Luxemburgo e de Lênin. Lukács não cessa de reafirmar também, paradoxal mente, a pertinência prática do marxismo. A experiência histórica recente, com sua seqüência inaudita e inesperada de acontecimentos extraordinários - a guerra imperialista, a crise do capitalismo e a vaga revolucionária que então varria a Europa -, só podia ser compreendida, segundo ele, pela vertente materialista. É, portanto, como instrumento de conhecimento do presente histórico, como forma de acesso privilegiado à compreensão do passado e do futuro da 
sociedade burguesa, que o método de M arx - atualizado por Rosa Luxemburgo e Lênin - constitui a base do marxismo ortodoxo.

A fidelidade à ortodoxia não reside mais, como ainda pensavam muitos adversários do "revisionismo" de Bernstein, na pretensão de preservar a "integridade estética" do sistema de M arx. Assenta-se na capacidade em destacar a essência de sua metodologia: a "dialética concreta e histórica"1.

Lukács ressalta os êxitos dessa metodologia na resolução de questões, de outro modo insolúveis, exaltando sua fertilidade nos escritos de Rosa Luxemburgo e de Lênin. M as não hesita em alertar que "muitos aspectos absolutamente essenciais do método de $\mathrm{M}$ arx caíram indevidamente no esquecimento", dificultando e quase impossibilitando uma compreensão apropriada da dialética.

U ma dimensão desse esquecimento tem nome próprio: G eorg W ilhelm Friedrich $\mathrm{H}$ egel. A omissão da dívida de $\mathrm{M}$ arx para com ele teria gerado três graves deturpações no marxismo da Segunda Internacional: a) a consideração da dialética em $M$ arx como um acréscimo estilístico a ser eliminado em nome do interesse científico; b) o não-reconhecimento de que categorias decisivas, utilizadas com freqüência em 0 capital, foram desenvolvidas antes na Ciência da lógica; c) a recusa da interpretação, estabelecida por Engels e reiterada por Plekhánov, que apresenta o movimento operário como "herdeiro da filosofia clássica alemã".

A busca de conexões metodológicas entre $H$ egel e $M$ arx, o propósito explícito de suscitar, por meio desse material e dessa orientação - repondo na ordem do dia - o debate sobre a dialética, inscreve-se em um programa mais abrangente. Trata-se de compreender a "coesão efetiva e sistemática" do método de $M$ arx ${ }^{2}$.

$\mathrm{N}$ a perseguição desse objetivo, Lukács parece afastar-se, como admite no "Prefácio", daquilo que seria a meta principal dessa linhagem: a interpretação de questões concretas da atualidade. As palavras de ordem em defesa do "marxismo ortodoxo" - uma vez posta assim a questão, em termos metodológicos - obrigam-no a um desvio (aparentemente fiel à sua essência histórica) que o leva a adotar como objeto de investigação ora a própria tradição, ora a interpretação da obra de M arx.

Pode-se dizer então que, a partir de $\mathrm{H}$ istória e consciência de classe, 0 marxismo sofre uma inflexão pela qual o critério de aferição da eficácia, da pertinência e inclusive da veracidade e da validade de qualquer obra que se pretenda herdeira do legado de $\mathrm{M}$ arx vincula-se à sua capacidade de dar conta, simultaneamente, de três objetos distintos: o mundo atual, a histó-
1. "Um marxistaortodoxo sério poderia [...] rejeitar todas as teses particulares de M arx, sem, no entanto, ser obriga do, por um único instante, a renunciar à sua ortodoxia marxista. 0 marxismo ortodoxo não significa, portanto, um reconhecimento sem crítica dos resultados da investigação de M arx, não significa uma 'fé' numa ou noutra tese, nem a exegese de um livro sagrado. Em maté ria de marxismo, a ortodoxia se refere antese exclusivamenteao método" (Lukács, 2003, p. 64).

2. M arx, em Miséria da filosofia, um dos livros maiscitadosao longo de $H$ istória e consciência de classe, lembra que "ame tafísica, a filosofia inteira, resumese, segundo H egel, a método" (2004, p. 120). Na seqüência, no entanto, ele apenas critica a metodologia de $\mathrm{H}$ egel e de Proudhon, sem expor deforma positiva sua versão da dialética. 
3. "M arxismo ocidental" éadenominação consagrada das tentativas de atribuir post hoc unidadeaum movimento que sedesenvolveu deforma independenteesem pla no preestabelecido. $\mathrm{Na}$ lista de Perry Anderson, selecionada apenas entre alemães, italianos efranceses, seuscomponentes seriam Georg Lukács, Karl Korsch, H erbert $M$ arcuse, Walter Benjamin, Antonio Gramsci, M ax H orkheimer, Galvano DellaVolpe, Henri Lefebvre, Theodor Adorno, Jean-Paul Sartre, Lucien Goldmann, Louis Althusser eLucio Colletti (cf. Anderson, 2004, p. 46).

4. Em polêmica com Eduard Bernstein, Karl Kautsky chega mesmo a dizer que "é o método que resulta da aplicação da concepp̧ão ma terialista da história à política: graças a ele 0 socialismo tornou-se uma ciência [...]. No socialismo marxista 0 essencial é o método, não osresultados" (apud H aupt, 1983, p. 369). ria do marxismo e a coerência, lógica ou histórica, da doutrina de $M$ arx.

Lukács pretende trazer ao primeiro plano determinados pressupostos e conseqüências metodológicos que não foram explicitados devidamente nem nos escritos de M arx, nem nos textos mais recentes de Rosa Luxemburgo ou de Lênin, todos eles dotados de uma assombrosa pertinência prática. Procura assim destacar que a compreensão da atual idade, ou melhor, a própria essência prática do marxismo depende de uma dimensão teórica, latente e nem sempre visível. Essa modesta pretensão constituiu apenas a pequena fresta de uma porta que posteriormente o marxismo dito "ocidental" nunca cessou de arrombar ${ }^{3}$.

Explicitação recorrente de premissas e determinações teóricas, latentes no conjunto da obra ou na doutrina de M arx, o marxismo ocidental conservou-se tributário de uma reiterada opção de conceder primazia ao mé todo. M as também cabe observar que, se essa linhagem, acompanhando a preocupação metodológica de $\mathrm{H}$ istória e consciência de classe, transformou o marxismo em um conjunto de "discursos do método", foi sob essa forma, hibernado em discussão teórica, que ele conseguiu preservar esse legado, quando as condições para levá-lo adiante tornaram-se adversas.

Visto retrospectivamente, o livro de Lukács aparece como a faísca detonadora de uma série logicamente previsível. N o entanto, tal posição de forma al guma estava posta de antemão. Afinal, a seqüência de autores e obras que configura o marxismo ocidental se estabeleceu sob circunstâncias bastante diversas da conjuntura teórica e prática na qual foram redigidos os artigos do livro.

H istória econsciência de classeimpactou os contemporâneos por motivos muito distintos de sua fortuna crítica posterior. $\mathrm{N}$ a Alemanha da década de 1920, a recepção destacou sobretudo o diagnóstico filosófico do presente histórico e sua tentativa de fornecer uma orientação para a ação. Com efeito, foram os autores do marxismo ocidental que deslocaram a ênfase, valorizando seu esforço de refinamento conceitual da metodologia marxista e da interpretação da obra de $\mathrm{M}$ arx.

Por fim, não há como ignorar que, ao contrário do que usualmente se propaga, o livro de Lukács não foi a primeira obra da vertente marxista a destacar o método. Ele foi precedido por toda uma tradição, vigorosa sobretudo na geração de Labriola, M ehring, Kautsky e Plekhánov. No entanto, seu antecessor mais ilustre foi, sem dúvida, o Anti-D ühring de Friedrich Engels4. 
A ciência como pedra de toque

A ênfase no método, no caso de Engels, parece ter sido involuntária. No "Prefácio à primeira edição" do Anti-D ühring, em junho de 1878, ele explica que, instado por companheiros da social-democracia alemã a combater as idéias de Eugen $D$ ühring, que se apresentava como o mais recente "adepto e reformador" do socialismo, aproveitou a "ocasião para expor de forma positiva os assuntos mais diversos [...] concepções sobre questões controversas que apresentam hoje interesse científico e prático mais geral" (Engels, 1976, p. 5).

0 êxito do livro surpreendeu Engels. Afinal, tratava-se da reunião de artigos já publicados em um importante, e amplamente difundido, órgão da imprensa operária alemã, o jornal Vorwärts. Além da demanda poucos anos depois por uma segunda edição, um opúsculo agrupando alguns capítulos do Anti-D ühring, com o título D o socialismo utópico ao socialismo científico, tornou-se rapidamente a mais popular introdução ao materialismo histórico, suplantando inclusive 0 manifesto comunista.

A ampliação do peso intelectual epolítico do marxismo no último quartel do século XIX e a expansão da atenção pública para tudo o que concernia a esse movimento, assim como a proibição do livro pelo império alemão, ajudam a compreender, pelo menos parcialmente, esse sucesso editorial, como relata o próprio Engels. Ele, que, entretanto, ainda procuraria outras explicações para a permanência do interesse por esses artigos, posto que, por ocasião da segunda edição (1885), Eugen D ühring havia se tornado um ilustre desconhecido. 0 segundo "Prefácio" acrescenta uma nova justificativa: "a crítica negativa resultou positiva; a polêmica transformou-se em exposição mais ou menos coerente do método dialético e da ideologia comunista defendida por $\mathrm{M}$ arx e por mim, numa série de domínios bastante vastos" (Idem, p. 9).

Somente a cautela e o comedimento de Engels em se posicionar como co-fundador do materialismo histórico explicam seu cuidado em evitar ressaltar aquilo que salta aos olhos: o Anti-D ühring, em sua "Introdução", reproduzida também em D o socialismo utópico ao socialismo científico, contém a apresentação sucinta de uma das lacunas da obra de M arx. Afinal, uma vez que esse texto foi escrito quando $M$ arx ainda estava vivo, e a feitura do livro contou inclusive com sua colaboração (na redação de um dos capítulos da parte consagrada à economia política), não é de se espantar que os contemporâneos, e mesmo a posteridade, tivessem enxergado 
5. Engels(1977b, p. 105) atribui a origem dessa nomenclatura, hojepouco usual, a Hegel. Ima gino quesetratadeuma apropriação bastantelivre deuma passagem daEnddopédia, naqual senomeia a primeira posição do pensamento relativo à objetividade como "metafísica" (1988, §§ 26-36). Com essetermo, $\mathrm{H}$ egel designatanto $0 \mathrm{sa}$ ber filosófico anterior à obra de Kant como um modo de "pensar diretamente os objetos", próprio da"filosofiaincipiente, das ciências, do agir e da prática cotidiana". ali a freqüentemente exigida e ansiosamente aguardada exposição da me todologia marxista.

No "Prefácio à segunda edição", Engels apenas alude, modestamente, à necessidade "de tornar a dialética, em toda a sua simplicidade e valor universal, acessível ao espírito", sem arrolar a apresentação do método entre as causas do sucesso editorial. N o entanto, não resta dúvida de que a chave desse êxito deriva, em grande parte, da recepção que tomou esse trecho, comum aos dois livros, como uma breve e autorizada exposição do método de M arx. A maior novidade dessa apresentação - que certamente não passou despercebida aos contemporâneos, tendo adquirido com o passar dos anos ares de "naturalidade" - consiste no esforço de Engels, completamenteausentena obra de $M$ arx, em descobrir e desenvolver as "leis da dialética" a partir da natureza.

Essa tentativa vincula-se à sua crença de que o incessante acúmulo de "descobertas" no âmbito das ciências naturais as conduz inevitavelmente a percorrer os trilhos da dialética. H averia inclusive, segundo ele, uma completa homologia entre esse domínio, com suas inúmeras mutações, e 0 reino da história, no qual a trama aparentemente fortuita dos acontecimentos segue as mesmas leis, também presentes no desenrolar do pensamento humano. N esse diapasão, Engels não hesita em afirmar que "uma concepção da história, ao mesmo tempo dialética e materialista, exige 0 conhecimento das matemáticas e das ciências naturais" (Idem, p. 10).

Pode-se ver aí, principalmente nessa última frase, a aposta de um pensador que dedicou parte de seus últimos anos de vida a acompanhar o avanço, então "vertiginoso", do conhecimento da natureza. 0 u mesmo o empenho em atualizar e complementar a doutrina de M arx, abordando assuntos pouco tratados por ele, que passaram a desempenhar um papel decisivo no debate ideológico da época. I mporta mais aqui, porém, destacar os delineamentos sobre os quais se firmou essa primeira versão do método de $M$ arx.

Em sua exposição da dialética, Engels, apesar de Ihe conceder a primazia, não a põe em cena sozinha. Junto e incessantemente contraposto a ela, emerge outro método filosófico, rival e concorrente, a "especulação metafísica"s. Para o adepto dessa metodologia, "as coisas e suas imagens no pensamento, os conceitos, são objetos isolados de investigação, objetos fixos, imóveis, observados um após o outro, cada qual de per si, como algo determinado e perene" (I dem, p. 20). A atribuição de rigidez ao objeto, a descrição precisa de seus contornos, a determinação do mundo como um conjunto de coisas acabadas e imutáveis, a observação estrita do princípio da 
não-contradição, a conexão irreversível de causa e efeito devem muito de sua plausi bilidade à proximidade com o senso comum. No entanto, adverte Engels, apesar de útil entre as quatro paredes de uma casa, o senso comum revela-se pouco apropriado quando se arvora em método científico.

D ispensa-se o esforço de aferir, pela via do confronto de resultados, a superioridade da dialética. Afinal, a própria metafísica, uma vez aplicada de forma consciente na investigação científica, abre caminho para a percepção de suas limitações. Unilateral e abstrato, esse método enreda-se, segundo Engels, em contradições insolúveis: atento a objetos determinados, não consegue enxergar as relações; congelado no presente, não concebe a gênese e a caducidade; concentrado na estabilidade das condições, não percebe a dinâmica, "obcecado pelas árvores, não consegue enxergar o bosque".

No molde de uma apresentação dicotômica, a dialética surge, ponto a ponto, como o oposto simétrico da metafísica. Não delimita de modo isolado os objetos, nem os toma como algo fixo e acabado. Ao contrário, investiga os processos, a origem e o desenvolvimento das coisas e as insere em "uma trama infinita de concatenações e de mútuas influências, em que nada permanece como era nem como existia". N ela, os pólos da antítese, apesar de todo antagonismo, "se completam e se articulam reciprocamente". A causa e o efeito, vigentes em um caso concreto, particular, "se diluem na idéia de uma trama universal de ações recíprocas, na qual as causas e os efeitos trocam constantemente de lugar e o que antes era causa toma, logo depois, o papel de efeito e vice-versa" (Idem, p. 21). Tampouco vigora 0 princípio da não-contradição, pois, pelo menos no mundo orgânico, "o ser é ele mesmo, o que é, e um outro".

Engels expõe brevemente essa dicotomia metodológica, à maneira do saber positivista predominanteem sua época, como uma seqüência evolutiva de etapas e resultados. $M$ as também como um eco do itinerário delineado por Hegel na Fenomenologia do espírito, ou seja, como "figuras" de uma progressão que é, simultaneamente, lógica e histórica.

A série inicia-se com uma intuição primitiva e simplista da dialética, presente na primeira filosofia grega. 0 mundo seria concebido como uma trama infinita de concatenações, na qual nada permanece. A primeira formulação consistente dessa "figura" pode ser atribuída a H eráclito, cuja filosofia é resumida por Engels na frase "tudo é e não é, pois tudo flui, tudo está sujeito a um processo constante de transformação, de incessante nascer e perecer" (I dem, p. 20). 
6. Asexceçõescitadaspor Engelssão 0 sobrinho de Rameau, de Diderot, e o D iscurso sobrea origem eosfundamentosda desgualdadeentreoshomens, de Rousseau.
Semelhante visão, embora "perfeitamente exata e congruente com a verdade das coisas", teria se mostrado pouco apropriada à investigação dos componentes que constituem o mundo. Assim, logicamente, teve de ceder lugar a uma concepção que, destacando os elementos de seu tronco histórico ou natural, examina-os "separadamente, cada um de per si, em sua estrutura, causas e efeitos". Historicamente, essa metodologia só se teria afirmado por completo a partir da segunda metade do século XV, com o nascimento das modernas ciências da natureza.

O s procedimentos dessas ciências, em especial "a análise da natureza em suas diferentes partes, a classificação dos diversos fenômenos e objetos naturais em determinadas categorias, a investigação interna dos corpos orgânicos segundo sua diferente estrutura anatômica" (I dem, p. 20), migraram, com Bacon e Locke, para a filosofia. Com raras exceções, deslocadas do eixo principal da corrente filosófica predominante, a filosofia moderna, segundo Engels, incluindo os pensadores franceses do século XVIII, deixou-se contaminar pela "especulação metafísica"6.

A filosofia do idealismo alemão e a trajetória das ciências naturais forneceram as premissas para a constituição de uma "nova etapa". 0 ritmo de desenvolvimento das ciências, marcado pelo acréscimo ininterrupto no estoque de dados, teria aguçado a consciência crescente - apesar da confusão que ainda vicejaria entre os cientistas - de que no método metafísico os fenômenos da natureza não são "encarados dinamicamente, mas estaticamente, não são considerados como situações substancialmente variáveis, mas como dados fixos, dissecados como materiais mortos e não apreendidos como objetos vivos" (I dem, ibidem). Esse avanço das ciências naturais, conjugado com as novas tendências da filosofia, possibilitou a restauração da dialética em uma forma superior, sintética.

$\mathrm{N}$ a apresentação de Engels, a dialética marxista, descrita a partir de suas origens, assume um caráter bifronte. Por um lado, consiste em uma modalidade de apreensão do mundo, em uma concepção que "encara as coisas e suas imagens conceituadas substancialmente em suas conexões, em sua filiação e concatenação, em sua dinâmica, em seu processo de gênese e caducidade". M as também se configura, por outro lado, como método "experimental", derivado de um saber "científico" que adota a explicação da natureza como "pedra de toque" (I dem, p. 21).

A el evação danatureza à condição deobjeto de estudo privilegiado para a compreensão da dialética não implica, porém, a desqual ificação explícita de outros domínios. A ênfasetal vez decorra apenas da necessidadededemarcar 
uma posição e um terreno ainda pouco assentados. A história humana ea atividade espiritual dela decorrente também se apresentam, em Engels, como camposférteisparaa investigação das "leis" da dialética.

Passíveis de apreensão sob a mesma metodologia, os territórios da natureza, da história e do pensamento já haviam sido alvos de uma explicação conjunta na obra de $\mathrm{H}$ egel, primeiro "estágio" do moderno renascimento da dialética. Essa tentativa, cujo mérito maior, segundo Engels, residiria no fato de ter colocado o método dialético novamente em pauta, fracassou por uma série de motivos: no fundo, limitações inerentes ao homem eà sua época.

Em rápidas considerações sobre a dialética hegeliana, Engels destaca sobretudo dois pontos. Primeiro, o contágio do método pelo idealismo, marca distintiva dessa filosofia. $\mathrm{N}$ a medida em que não postula como fonte das idéias as coisas e os fenômenos, antes visualizando estes como projeções de uma idéia "existente não se sabe onde, antes da existência do mundo" (Idem, p. 22), H egel teria subvertido, revirando do avesso, a concatenação efetiva do mundo. D esse modo, foi impelido a adotar posições "acomodatícias, artificiosas, arbitrárias". Afora esse pendor idealista, pouco convincente para cérebros educados nas modernas ciências da natureza, a filosofia hegeliana encontrar-se-ia perpassada por uma contradição insolúvel entreo método, quenão aceita a afirmação de verdades absolutas, e o si stema, que se apresenta como "resumo e compêndio" de uma verdade absoluta.

Tais observações configuram, no entanto, mais que uma interpretação própria da obra de $\mathrm{H}$ egel, desenvolvida com detalhes posteriormente em Ludwig Feuerbach e o fim da filosofia clássica alemã, de 1888, e na qual ressoam al gumas das determinações críticas estabelecidas na década de 1840 pelos jovens-hegelianos. A ênfase de Engels em temas clássicos da recepção do pensamento de Hegel, mas nem por isso menos polêmicos, como o "platonismo" e o "modelo de sistema", indica as balizas mínimas a partir das quais teriam sido estabelecidas, segundo sua ótica, as premissas do marxismo.

Contra essa "idéia existentenão se sabeonde", Engels propõeo restabelecimento do materialismo. M as não em sua versão racionalista, "metafísica e mecânica", predominantenafilosofiafrancesa do século XVIII, cujo conteúdo jásehavia corporificado na sociedade burguesa. Postula um materialismo apto a compreender o dinamismo dahistóriaedanatureza, um materialismo que, apesar de consciente da "total inversão em que o idealismo al emão incorrera", tenha como qualificação maisapropriada o termo "dialético". 
0 materialismo, nessa nova versão, "substancialmente dialético", não considera mais a natureza, como fizeram os filósofos franceses e mesmo $\mathrm{H}$ egel, como um todo permanente e inalterável. Resumo organizado dos novos progressos das ciências naturais - cujo cerne pode ser localizado na tese segundo a qual a natureza tem também sua história no tempo, o que significa que as espécies e os organismos, assim como os mundos que elas habitam, nascem e morrem -, o materialismo proposto por Engels prescinde do espírito sistemático: "um sistema universal e compacto, definitivamente plasmado, no qual se pretende enquadrar as ciências da natureza e da história é incompatível com as leis da dialética" (I dem, p. 23).

0 alvo de Engels, no entanto, aponta para algo mais que a crítica do apego de H egel à sistematização. Segundo ele, nosúltimos anos, as ciências que cuidam especificamente dos dois objetos prioritários da dialética, a natureza e a história, teriam se desenvolvido o suficiente para atingir a maioridade. U ma vez incorporada a dialética, para essas ciências e para o novo materialismo que Ihes é inerente, "já não há necessidade de uma filosofia superior", de um saber "especialmente consagrado a estudar as concatenações universais". Assim, cabe observar que, ao contrário da percepção pela posteridade no interior do próprio campo marxista, o "socialismo científico", tal como proposto por Engels, não resulta de uma inversão da filosofia ideal ista de $\mathrm{H}$ egel, pois não se autocompreen de mais como filosofia.

No relato histórico das origens da dial ética material ista, Engels acompanha deforma concomitanteatrajetória de duasfontes, afilosofia ea ciência. Essa bifurcação não deixa de repercutir em sua determinação do método, ora descrito com traços de concepção filosófica, ora como pura metodologia científica. $\mathrm{N}$ ada disso, entretanto, impede o "socialismo científico" de se apresentar como superação dessa dicotomia. 0 novo materialismo, na medida em que se qualifica a si próprio como ciência, não se propõea ultrapassar apenas o pensamento de H egel. É a própria filosofia, em sua totalidade, que se encontra sujeita à condenação, explicitada na famosa frase: "tudo 0 mais se dissolvena ciência positiva da natureza eda história".

A dialética do processo histórico

H istória e consciência de classe, por sua vez, retoma deliberadamente a primazia do método. Antes de expor seu conteúdo, Georg Lukács, no propósito de recuperar a configuração original da dialética, estabelece como premissa uma determinação que reputa essencial, enunciada de forma bre- 
veno dístico: "A dialética materialista éuma dialética revolucionária” (2003, p. 64).

Lukács desdobra essa fórmula em diversas variantes - dialética como ál gebra, como veículo da revolução etc. Com isso, busca ressaltar a importância da metodologia na "determinação das condições de possi bilidade da unidade entre teoria e prática”, destacando o vínculo estreito que articula, no marxismo, o método com a transformação do mundo.

Ao ressaltar esse nexo, Lukács indica sua preocupação em transpor os termos sob os quais a questão do método foi apresentada, sobretudo por Eduard Bernstein e Rudolf H ilferding, durante o período de proeminência política e teórica da Segunda Internacional. Ele adverte que tal discussão não pode ser travada nos parâmetros de um enfoque estritamentegnosiológico, nem ser restringida pelo esquadro de uma indagação puramente científica, na qual o "método pode ser rejeitado ou aceito, segundo o estado da ciência, sem que a atitude fundamental diante da realidade e do seu caráter modificável ou imutável sofra a menor mudança" (I dem, p. 68).

$\mathrm{N}$ a origem desses equívocos estaria, segundo Lukács, nada mais nada menos que a versão engelsiana da dialética. No mínimo como parcela responsável, ai nda que indiretamente, pela adoção posterior de um procedimento que se quer estritamente científico embora, na verdade, permaneça aquém do método de $M$ arx.

C aso interesse uma distinção que não deixa de redundar em uma classificação um tanto quanto compartimentada, a contestação da apresentação engelsiana da dialética, levada a cabo por H istória e consciência de clas se, desdobra-se, de modo geral, em dois movimentos distintos. Lukács ora avalia a exposição concisa da dialética, ensaiada na "Introdução" do AntiD ühring, pela aplicação que outros autores Ihe deram, ora a julga por si mesma, tomando-a como um todo coerente, ainda que independente e apartada do conjunto da obra de Engels.

H istória e consciência de classe aproxima, até quase a indistinção, a dialé tica compendiada por Engels da apropriação cientificista do método, desdobrada pela geração subseqüente. Tal associação permite inferir - conclusão compartilhada pelos dois lados que se enfrentaram por ocasião e em torno da publicação do livro de Lukács - que Engels, apesar de suas conhecidas divergências em relação à prática política reformista, não teria deixado de calçar o terreno para tais deturpações.

Por outro lado, independentemente da questão da legitimidade da utilização, no mínimo polêmica, da obra do último Engels pelos mentores da 
Segunda Internacional (Eduard Bernstein em particular), alguns pontos precisos da exposição engelsiana (fortalecendo a veracidade da inferência acima citada) foram incluídos por Lukács diretamente no rol dos fatores que, jogando "indevidamente no esquecimento aspectos absolutamente essenciais", dificultaram uma ad equada compreensão da dialética.

Entre eles, um ponto central sem dúvida consiste na observação de que Engels teria descurado da "essência prática da teoria". A conseqüência maior de tal descuido - grave entre marxistas - reside em sua contribuição, mesmo que involuntária, para relegar a segundo plano ou pelo menos a uma esfera distinta a questão da transformação da realidade. Semelhante desatenção pode ser atribuída à ênfase concedida por Engels ao caráter científico da dialética ou pelo menos ao vínculo, que promoveu e intensificou, entre o método do marxismo e o desenvolvimento científico.

Lukács recapitula, uma a uma, as determinações da dialética engel siana: dissolução da rigidez dos conceitos e dos objetos que lhes correspondem, passagem contínua de uma determinação a outra, permanente superação dos contrários, substituição da causalidade unilateral e rígida pela interação recíproca. M aculadas pela subordinação do marxismo às ciências naturais ou pelo fato de não se levar em conta a dimensão prática da teoria, ou melhor, uma vez ausente a consideração metodológica da "relação dialética do sujeito e do objeto no processo da história", Lukács avalia que tais determinações seriam insuficientes para suplantar a perspectiva meramente contemplativa, própria da ciência burguesa.

$N$ unca é demais lembrar o choque causado pela reivindicação de autenticidade - totalmente inusitada dentro das fileiras do marxismo -, manifestada nessa acusação e reafirmada com todas as letras no "Prefácio" de H istória e consciência de classe. Lukács se auto-atribui representante, contra o próprio Engels, do ponto de vista do marxismo ortodoxo.

D esviando, entretanto, a atenção do escândalo ou mesmo das conseqüências políticas de semel hante crítica, torna-se possível discernir nos termos da acusação, na contraposição implícita, uma primeira determinação positiva da versão lukacsiana da dialética. A dualidade, enfatizada reiteradamente, entre os pólos contemplativo e ativo (prático) recobre, mas também contribui para delimitar, uma distinção mais essencial que opõe, de um lado, a ciência burguesa e, de outro, a ação revolucionária. Tal diferença, por sua vez, permite esclarecer as diversas modalidades de âncoras que sustentam as versões, bastante distintas, da dialética conforme Engels ou segundo Lukács. 
A interpretação elaborada em H istória e consci ência de classeacusa Engels de ter deixado de "investigar, tanto na teoria como na maneira como ela penetra nas massas, esses momentos e essas determinações que fazem da teoria, do método dialético, o veículo da revolução" (I dem, p. 65). N egligenciando os aspectos históricos ou mesmo políticos da questão, ou seja, a partir de um ponto de vista estritamente lógico, essa censura assenta-se sobretudo em uma discrepância conceitual, aqui reduzida ao mínimo: Lukács considera a "condição prévia da dialética revolucionária", seu momento indispensável, uma determinação totalmente ausente da exposição engelsiana do método - "a unidade de teoria e prática".

A importância dessa determinação, responsável, de certo modo, por um novo desenho da dialética, vai além de sua capacidade em configurar, à maneira de um pólo magnético, uma reorganização geral das articulações metodológicas. Ela se manifesta também na forma como Lukács articula teoria e método. Embebido nessa relação, o método dialético, "essência teórica da teoria" marxista, possibilita uma outra redefinição pela qual a teoria passa a ser concebida como "expressão pensada do próprio processo revolucionário".

Tudo isso não resulta apenas da ancoragem da dialética na relação entre teoria e prática. D eve ser atribuído sobretudo ao intermediário que Lukács posiciona como mediador entre esses dois termos. Como se sabe, os desdobramentos da "essência prática da teoria", consolidados no lema "unidade de teoria e prática", dependem, no arcabouço de H istória e consciência de classe, da elevação conceitual do proletariado à condição de sujeito eobjeto do processo histórico, mediando assim a relação entre consciência e realidade:

Somente quando for dada uma situação histórica na qual o conhecimento exato da sociedade tornar-se, para uma classe, a condição imediata de sua auto-afirmação na luta; quando, para essa classe, seu autoconhecimento significar, ao mesmo tempo, o conhecimento correto de toda a sociedade; quando, por conseqüência, para tal conhecimento, essa classe for, ao mesmo tempo, sujeito e objeto do conhecimento e, portanto, a teoria interferir de modo imediato e adequado no processo de revolução social, somente então a unidade da teoria e da prática, enquanto condição prévia da função revolucionária da teoria, será possível (I dem, p. 66).

A indiferença em relação ao vínculo que une dialética e proletariado teria contribuído, ou até mesmo provocado, a capitulação metodológica do marxismo às normas do saber burguês. Esse feito foi, em geral, compu- 
tado sobretudo como resultado da apropriação da exposição esboçada no Anti-D ühring pelos teóricos da Segunda Internacional e quase nunca como uma responsabilidade do próprio Engels. Lukács, no entanto, como vimos, em sua reconstituição da questão, deliberadamente polêmica, atribui pesos idênticos à apropriação dos seguidores e à versão engelsiana do mé todo dialético.

Além do descuido em relação à dimensão revolucionária ou, em termos mais brandos, à determinação prática da teoria, manifesta na despolitização do método, inerente à sua ancoragem nos progressos da ciência, Lukács acrescenta outra acusação. Tanto Engel scomo a geração subseqüenteteriam adotado de forma indiscriminada as ciências naturais como regra emodelo.

H istória e consciência de classe atribui essa subordinação da teoria e do método a ditames e desdobramentos de uma tradição de conhecimento para a qual é indiferente a consideração da dimensão histórica. M as também reitera que semelhanterestrição resulta, paradoxal mente, deuma hybris: Engels teria se afastado do modelo marxista - que concebe a teoria, atenta às relações que o saber estabelece com o objeto, como "expressão pensada do próprio processo revolucionário" - na medida em que não restringiu a aplicabilidade da dialética à realidade histórico-social:

Os equívocos surgidos a partir da exposição de Engels sobre a dialética baseiam-se essencialmenteno fato de que Engels- seguindo o mau exemplo deH egel - estende o método dialético também para o conhecimento da natureza. No entanto, as determinações decisivas da dialética (interação entre sujeito e objeto, unidade de teoria e prática, modificação histórica do substrato das categorias como fundamento da sua modificação no pensamento etc.) não estão presentes no conhecimento da natureza (Idem, p. 69, nota).

Antetamanha insistência, impõese a ressalva: Lukács não estaria sendo demasiado drástico, aproximando indevidamente os dois patamares, o das determinações da versão da dialética formulada por Engels com o das apropriações perpetradas por seus seguidores no ambiente intelectual (e político) da Segunda Internacional?

Tal indagação adquire maior pertinência quando se observa que Eduard Bernstein, por exemplo, inverteu completamente a estratégia de Engels. Em lugar de procurar oxigenar as ciências da natureza, investigando, em sua lógica própria, afinidades que apontem no sentido de uma progressiva aproximação ao procedimento dialético, Bernstein considera o método 
corriqueiro - empírico e matematizante, logo não dialético - das ciências naturais como modelo adequado para o marxismo ${ }^{7}$. N ão seria, portanto, muita caturrice de Lukács associar coisas tão distintas como a idolatria do método das ciências naturais, por parte dos teóricos da Segunda Internacional, e a (ilusória) percepção engelsiana de que a natureza também estaria sujeita às leis da dialética?

As passagens de H istória e consciência de classe que procuram refutar a incorporação, por marxistas, do método das ciências naturais, apesar de assentarem sua bateria unicamente sobre os epígonos de Engels, não deixam de reforçar essa continuidade. $\mathrm{N}$ ão dissociam, como seria de se espe rar, interpretações dialéticas ou não dialéticas dos métodos das ciências naturais. Antes, concedem o mesmo tratamento, embora nunca o mesmo espaço, às duas metodologias.

O primeiro ensaio deH istória e consciência de classe ("O queé marxismo ortodoxo"), por exemplo, indaga acerca do significado metodológico do empirismo. Lukács não se limita aí à observação de que a mera enumeração dosfatos relevantes para o conhecimento - que, como se sabe, varia conforme os objetivos do saber - já pressupõe uma interpretação e, com ela, um método e uma teoria, o que aliás se tornou lugar comum após H egel ou M ax Weber. Atribui a adaptabilidade dos dados percebidos ao padrão de conhecimento imposto pelas regras das ciências naturais - a incorporação ao saber de fatos "puros" por meio de procedimentos tais como a observação, a abstração e a experimentação - a uma ilusão socialmente necessária, constitutiva da própria sociedade capitalista.

Recorrese assim à teoria do fetichismo da mercadoria, delineada por M arx em 0 capital. A redução dos fenômenos à sua dimensão quantitativa, condição prévia de sua expressão "em números e em relações numéricas", decorre do próprio desenvolvimento histórico do capitalismo:

0 caráter fetichista da forma econômica, a reificação detodas as relações humanas, a extensão sempre crescente de uma divisão do trabal ho, que atomiza abstratamentee racional menteo processo de produção, sem se preocupar com as possibilidades e capacidades humanas dos produtores imediatos, transformam os fenômenos da sociedade e, com eles, sua apercepção (I dem, p. 72).

A teoria de Lukács, ao adotar como vetor explicativo o fenômeno do fetichismo, descola-se substancialmente das considerações de Engels. N o entanto, sua descrição dos procedimentos correntes no saber tradicional, à
7. Segundo Bernstein, os desvios de $M$ arx dos trilhos da ciência deveriam ser atribuídosàsua desconsideração dosdadosempíricos, matriz de uma série de "construçõesarbitrárias". Assim, seus equívocos resultariam principalmentedo uso indiscriminado do método dialético (cf. Bernstein, 1982, pp. 111-133). 
primeira vista, mantém-se consoante com as determinações do "método metafísico", estabelecidas em Anti-D ühring. H istória e consciência de classe apresenta o procedimento em que "um fenômeno da vida é transportado, realmente ou em pensamento, para um contexto que permite estudar as leis às quais ele obedece sem a intervenção perturbadora de outros fenômenos" (I dem, p. 71), matriz dos "sistemas parciais isolados e isolantes", como resultado de uma determinação própria e histórica (isto é, nem natural, nem perene) da sociedade burguesa.

Conclui, assim, que os equívocos resultantes da adoção dessa metodologia padrão tornam-se evidentes quando se confronta a necessidade - inerente ao método das ciências naturais - de trabal har com dados constantes e invariáveis com a realidade, permanentemente mutável, da evolução histórica. Por conseguinte, a simples consideração histórica dos fatos parece suficiente para pôr em dúvida a exatidão e a objetividade desse método.

D essa forma, Lukács reitera, ainda que pontualmente, os ensinamentos de Engels, a quem aliás concede os créditos necessários. M as não se trata de uma incorporação tout court do método apresentado no Anti-D ühring. $A$ ênfase engel siana na incessante mutabilidade dos fatos adquire, em Lukács, uma função terapêutica, na medida em que possibilita uma inicial apreensão dos erros inerentes a uma metodologia explicitamente não dialética.

Lukács só acompanha a exposição engelsiana até esse ponto. Q uando se trata de restabelecer a objetividade do conhecimento, ou mesmo quando 0 diagnóstico aprofunda-se, buscando esclarecer os fatores que concedem ao método das ciências naturais sua espantosa naturalidade, as determinações com que configura sua versão da dialética tomam uma direção oposta ao caminho ensaiado por Engels.

0 vetor principal não consiste na consideração de que os fatos estão envolvidos num processo de contínua mudança, mas antes na observação de que "são, precisamente na estrutura de sua objetividade, produtos de uma época histórica determinada: a do capitalismo" (I dem, p. 74). 0 tra-

8.Segundo Lukács, "essa dupla determina ção, essereconhecimento [do caráter necessát rio da aparência] e essa superação simultâneado ser imediato, constitui justamente a relação dialética" (2003, p. 76). tamento histórico-dialético a que os dados devem ser submetidos depende assim da apreensão de seu condicionamento histórico, ou melhor, de suas mediações. D essa forma, Lukács instaura uma distinção primordial entre "sua existência real e seu núcleo interior", entre representações e conceitos, premissa indispensável à compreensão do caráter necessário da "aparência fenomenal"8.

A objetividade do conhecimento, por conseguinte, só se torna possível quando as determinações fatuais, à primeira vista "simples, puras, imedia- 
tas e naturais" no âmbito do capitalismo, perdem sua condição de dados inquestionáveis e passam a ser compreendidas como momentos de uma "totalidade concreta como reprodução intelectual da realidade". Sem a apreensão dos condicionamentos históricos, bem como da necessidade inerente à forma que sua apreensão adquire na sociedade capitalista, permanecese ainda no campo oposto:

Aquela "ciência" que reconhece como fundamento do valor científico a maneira como os fatos são imediatamente dados, e como ponto de partida da conceitualização científica sua forma de objetividade, coloca-se simples e dogmaticamente no terreno da sociedade capitalista (I dem, p. 74).

Consuma-se assim o veredicto acerca da versão engelsiana da dialética. Esta se apresenta como insuficiente, uma vez que não vai além da simples constatação de mutabilidade dos fatos (que pode inclusive se dar dentro de uma mesma ordem social, desde que considerada temporalmente), ou de sua inclusão em um processo contínuo e ininterrupto. Lukács reivindica que a compreensão do caráter histórico de um dado fatual qualquer esteja vinculada à apreensão dos condicionamentos que o configura como momento determinado de uma totalidade sócio-histórica.

As determinações da dialética engel siana (dissolução da rigidez dos conceitos e dos objetos que Ihes correspondem, passagem contínua de uma determinação a outra, permanente superação dos contrários, substituição da causal idade unilateral e rígida pela interação recíproca) nada significam, segundo Lukács, sem a consideração metodológica da "relação dialética do sujeito e do objeto no processo da história".

A perspectiva da totalidade

O s equívocos da exposição engelsiana da dialética, entretanto, não decorrem apenas de uma indevida incorporação do conhecimento da natureza e da cientificidade que Ihe é própria. Segundo Lukács, assentam-se também em uma compreensão incorreta da relação entre $M$ arx e $H$ egel.

Como se sabe, o último Engels apresenta a metodologia do marxismo como uma confluência na qual um dos troncos consiste na inversão materialista da dialética hegeliana - premissa indispensável para a superação do "platonismo" que lhe é característica. A possibilidade dessa metamorfose, de certo modo, seria fornecida pelo próprio caráter revolucionário do mé 
todo hegeliano, em flagrante e permanente contradição com o espírito conservador do sistema. 0 descompasso entre a dialética - incompatível por definição com afirmações absolutas - e o empenho sistemático de H egel em apresentar sua filosofia como "resumo e compêndio" de uma verdade absoluta impõe, na visão de Engels, o giro materialista como um desdobramento quase diria necessário desse pensamento.

Lukács não rejeita propriamente a tese que considera o materialismo histórico o "herdeiro do idealismo alemão". Antes, procura até mesmo aprofundá-la, e para tanto não hesita em alterar o qualificativo da relação entre $\mathrm{H}$ egel e M arx de "desdobramento" para "prolongamento". Entretanto, ao contrário de Engels, Lukács concede pouca ênfase ao giro materialista. Segundo ele, a maneira como se praticou essa inversão (em Engels e em seus epígonos na Segunda Internacional) não deixou de provocar um enfraquecimento do empenho sistêmico, acarretando uma fragmentação que dispersou o conhecimento em esferas autônomas, à semehança da teoria de $M$ ax Weber.

Em contraposição a esse diagnóstico, Lukács salienta que M arx conseguiu transmudar a dialética hegeliana em "ál gebra da revolução" sobretudo porque se ateveà sua matriz principal (totalmente ignorada por Engels), à categoria, ou melhor, ao ponto de vista da totalidade.

0 domínio do todo sobre as partes, configurado por meio da apreensão dos múltiplos fenômenos parciais como momentos do todo, como parcelas de um mesmo processo, torna-se, em H istória e consciência de classe, fator decisivo para a definição do campo marxista. Identificado com a essência do método de M arx, o ponto de vista da totalidade sobrepujaria inclusive outras determinações, consideradas até então suficientes para delimitar suas diferenças diante da ciência burguesa, como o "predomínio de motivos econômicos na explicação da história" ou mesmo a prática de "contrapor à sociedade burguesa conteúdos revolucionários".

Segundo essa perspectiva, que ressalta a importância da categoria "totalidade" para a compreensão da metodologia do materialismo histórico, a aproximação entre $M$ arx eH egel seria maior que a proximidade entre $M$ arx e a maioria dos teóricos, declaradamente marxistas, da social-democracia:

M esmo a polêmica materialista contra a concepção "ideológica” da históriaédirigida bem mais contra os epígonos de $H$ egel do que contra o próprio mestre que, a esse respeito, estava muito mais próximo de $M$ arx do que este pôde imaginar em sua luta contra a esclerose "idealista" do método dialético. 0 idealismo "absoluto" dos 
epígonos de $\mathrm{H}$ egel chega, com efeito, a dissolver a totalidade primitiva do sistema, a separar a dialética da história viva [...]. Contudo, o materialismo dogmático dos epígonos de $\mathrm{M}$ arx repete a mesma dissolução da totalidade concreta da realidade histórica. Se o método dos epígonos de M arx não degenera, como o dos epígonos de $\mathrm{H}$ egel, num esquematismo intelectual vazio, ele se atrofia numa ciência específica e mecanicista, em economia vulgar (Idem, pp. 116-117).

U ma primeira conseqüência de se considerar a dialética conforme a perspectiva da totalidade seria, portanto, a exigência de superar as distinções abstratas sobretudo no que tange à relação entre sujeito e objeto do conhecimento, premissa inicial da constituição de domínios autônomos de pesquisa, separados em decorrência da divisão intelectual do trabal ho eda especialização científica. Trata-se de redirecionar o conhecimento para considerar a sociedade uma totalidade, recomendação enfatizada na célebre passagem: "Para o marxismo, em última análise, não há, portanto, uma ciência jurídica, uma economia política e uma história etc. autônomas; mas somente uma ciência histórico-dialética, única e unitária, do desenvolvimento da sociedade como totalidade" (Idem, p. 107).

Certamente, Lukács não ignora a necessidade, durante o processo de elaboração do conhecimento, de isolar e abstrair elementos de um amplo campo de investigação, de focalizar complexos de problemas ou ainda de condensar conceitos de um dado campo de estudos. Para ele, porém, o decisivo consiste em saber se esse isolamento é apenas um meio para o conhecimento do todo, inserido como momento determinado de uma cone xão total, ou se o conhecimento abstrato de regiões parciais isoladas preserva sua autonomia, convertendo-se, à maneira da ciência burguesa, em finalidade própria.

No transplante da dialética de $\mathrm{H}$ egel para M arx nem tudo, como seria de se esperar, permanece idêntico. $N$ a medida em que, para Lukács, o mé todo de $\mathrm{M}$ arx apresenta-se "como a continuação conseqüente do que $\mathrm{He}$ gel havia almejado, mas que não obtivera concretamente" (I dem, p. 92), o "prolongamento" da dialética hegeliana inclui algumas correções. No que tange à perspectiva da totalidade, a modificação mais substancial diz respeito à necessidade de que essa categoria determine não só o objeto, mas também o sujeito do conhecimento.

A ciência burguesa, em especial a economia clássica, mantém-se presa à consideração dos fenômenos sociais a partir da perspectiva do indivíduo (o agente capitalista). D espreza-se assim, na perspectiva de Lukács, simulta- 
9. Lukács contesta a separação, própria da social-democraciaalemãe levada ao extremo por Rudolf Hilferding (cf. "Prefácio" a 0 capital financeiro [1985]), entre o marxismo como ciência objetiva e o socialismo como tendêncialatentena sociedade. neamente, duas características primordiais da dialética - "a exigência da totalidade tanto como objeto determinado como sujeito que determina".

H egel, por sua vez, embora encare o objeto como totalidade, só preenche metade dos requisitos, já que hesita entre o "ponto de vista do 'grande homem' e o do espírito abstrato do povo" (Idem, p. 108).

M arx, porém, particularmente em 0 capital, na medida em que "considera os problemas de toda a sociedade capitalista como problemas das classes que a constituem, sendo a dos capital istas ea dos proletários apreendidas como conjuntos", atinou para o papel-chave do conceito de classe. D escortina assim um sujeito que, na sociedade moderna, "para se pensar a si mesmo é obrigado a pensar o objeto como totalidade".

Parte-se, portanto, da premissa de que "o ponto de vista do indivíduo não pode levar a nenhuma totalidade, quando muito pode levar a aspectos de um domínio parcial, mas na maioria das vezes somente a algo fragmentário: a 'fatos' desconexos ou a leis parciais abstratas". N esse diapasão, "a totalidade só pode ser determinada se o sujeito que a determina é ele mesmo uma totalidade" (Idem, p. 107). Lukács reconstitui assim o marxismo como uma forma de saber umbilicalmente vinculada ao proletariado 9 .

Afinal, uma vez quea superioridade científica e metodológica do ponto devista declassesobrea perspectiva individual assenta-seno fato de que "somente a classe, por sua ação, pode penetrar a realidade social etransformá-la em sua totalidade" (I dem, p. 125), aúnica classecapaz depromover a esperada modificação social, garantindo, ao mesmo tempo, a unidade de teoria e prática, seria o proletariado. Recuperando uma frase célebre de M arx, no $M$ anifesto do Partido Comunista, que identifica o proletariado como executor da sentença de morte proferida pela burguesia contra si mesma, Lukács conclui queo proletariado, "ao reconhecer sua si tuação, age, eao combater o capitalismo, reconhece sua situação" (I dem, p. 127).

0 giro principal efetivado por $\mathrm{M}$ arx em relação ao método de $\mathrm{H}$ egel, portanto, segundo Lukács, não consiste precisamente na passagem do idealismo para o materialismo - como às vezes sugere o próprio $M$ arx, e Engels não cessava de reiterar. 0 mais decisivo foi a transi ção do ponto de vista do indivíduo para a perspectiva das classes sociais.

H istória e consciência de classe ressalta ainda que, ao adotar a perspectiva da totalidade, $\mathrm{M}$ arx teria transplantado diretamente de $\mathrm{H}$ egel não apenas a consideração de todos os fenômenos parciais como momentos do todo ou a identidade entre sujeito e objeto, mas também a compreensão do processo dialético como unidade de pensamento e experiência. Segundo ele, esse 
modo de conceber o vínculo entre lógica e história tornou-se um fator determinante no recente renascimento do marxismo, consagrado nas obras decisivas de Lênin e Rosa Luxemburgo - respectivamente, 0 estado e a revolução e A acumulação do capital.

Lukács detecta a manifestação dessa unidade de conceito etemporalidade em partes pouco valorizadas e mal compreendidas desses livros, em trechos dedicados a balanços históricos da literatura produzida sobre a questão em pauta, como éo caso dos segundo e terceiro capítulos do livro de Lênin, "A experiência de 1848-1851" e "A experiência da Comuna de Paris (1871)", edasegunda parte do de Rosa, "Exposição histórica do problema".

D iferentemente do ato de "tomar em consideração os precursores", típico da ciência burguesa (mas também dos teóricos da social-democracia), distante da enumeração infindável e despropositada do "especialista", Lênin e Rosa teriam conseguido desenvolver nesses capítulos a tão almejada unidade de teoria e história:

D evido a essa relação com as tradições de método e de exposição referentes a $M$ arx e a H egel, Lênin fez da história do problema uma história interna das revoluções européias do século XIX; a abordagem histórico-literária dos textos por Rosa Luxemburgo se desenvolve numa história das lutas em torno da possibilidade e da expansão do sistema capitalista (I dem, p. 118).

Esse método, segundo Lukács, está presente em M arx já em "sua primeira obra acabada, completa e madura", M iséria da filosofia, por meio da crítica direta das verdadeiras fontes de Proudhon (Ricardo e H egel). E estrutura também outros livros de $\mathrm{M}$ arx, como 0 capital e Teorias sobre a mais-valia, ainda que sob uma forma modificada e menos nítida.

D esse modo, o procedimento de reconstruir o processo histórico por meio de um exame dialético da literatura disponível acerca dos temas abordados atesta mais que a pertinência e a eficácia do predomínio da perspectiva da totalidade. Indica também que:

0 método filosófico de $\mathrm{H}$ egel, que sempre foi - de maneira mais convincente na Fenomenologia do espírito - história da filosofia e filosofia da história ao mesmo tempo, jamais foi abandonado por $\mathrm{M}$ arx em relação a esse ponto essencial. Pois, a unificação hegeliana - dial ética - do pensamento edo ser, a concepção de sua unidade como unidade e totalidade de um processo, formam também a essência da filosofia da história do materialismo histórico (Idem, p. 116). 
Lukács explicita assim o método inerente, ainda que inconsciente, de Lênin e Rosa Luxemburgo como a realização efetiva do programa do idealismo alemão. D esse modo, não deixa de situar, pelo menos no que tange a essas obras específicas, esses dois autores como pontos inaugurais daquele movimento que a posteridade nomeou como "marxismo ocidental".

A junção, que teria sido promovida desde $M$ arx, de história da filosofia efilosofia da história, do a priori e do a posteriori, da teoria eda experiência, do lógico e do histórico, serve também de guia para quem queira evitar os dilemas em que se enredam as tentativas de, num trânsito de mão única, compreender as formações "ideológicas", típicas da superestrutura, unicamente a partir da base objetiva da sociedade.

Sejaqual for o temaem discussão, o método dialético tratasem predo mesmo problema: o conhecimento da totalidadedo processo histórico. Sendo assim, osproblemas "ideológicos" e "econômicos" perdem para elesua estranheza mútua einflexível ese confundem um com o outro. A história deum determinado problema torna-seefetivamenteuma história dosproblemas. A expressão literária ou científicade um problema aparece como expressão de uma totalidade social, como expressão de suas possibilidades, de seus limites e de seus dilemas. 0 estudo histórico-literário do problema acaba sendo o mais apto a exprimir a problemática do processo histórico. A história da filosofia torna-sefilosofia dahistória(Idem, p. 117).

É, portanto, sob a égide da filosofia da identidade que a categoria da totalidade justifica, em Lukács, o trânsito de mão dupla entre fenômenos objetivos e subjetivos, economia e superestrutura, que se tornará, a partir de então, uma das marcas distintivas do marxismo ocidental.

Referências Bibliográficas

An derSo N, Perry. (2004), Considerações sobreo marxi mmo ocidental. São Paulo, Boitempo. BERN STEIN, Eduard. (1982), Las premissasdel socialismo y lastareasdela socialdemocracia.

M éxico, Siglo Veintiuno.

Engels, Friedrich. (1976), Anti-D ühring. São Paulo, Paz e Terra. . (1977a), D o socialismo utópico ao socialismo científico. In: . Textos. São

Paulo, Edições Sociais, vol. 1. - (1977b), Ludwig Feuerbach e o fim da filosofia clássica alemã. In:

Textos. São Paulo, Edições Sociais, vol. 1. 
H AUPT, G eorges. (1983), “M arx e o marxismo”. In: H obsbaw m, Eric (org.). H istória do marxismo. Rio de Janeiro, Paz eTerra, vol. 1.

H egel, G. W. F. (1968), Ciencia de la lógica. Buenos Aires, Solar. - (1988), Enciclopédia das ciências filosóficas em epítome. Lisboa, Edições 70. - (1992), Fenomenologia do espírito. Petrópolis, Vozes.

H Ilferding, Rudolf. (1985), 0 capital financeiro. São Paulo, N ova Cultural.

LÊNIN, V ladimir Ilitch. (1979), A revolução proletária e o renegado Kautsky. São Paulo, Ciências H umanas. . (1986), 0 estado e a revolução. São Paulo, H ucitec.

LuKÁCs, G eorg. (2003), H istória econsciência de classe. Estudos sobrea dialética marxis ta. São Paulo, M artins Fontes.

Luxem burgo, Rosa. (1974), A crise da social-democracia. Lisboa, Presença. - (1976), A acumulação do capital. Rio de Janeiro, Zahar.

M ARX, Karl. (1983), 0 capital. Crítica da economia política. São Paulo, Abril Cultural. - (1988), M anifesto do Partido Comunista. Petrópolis, Vozes. - (2004), A miséria da filosofia. São Paulo, Ícone.

\section{Resumo}

A dialética como discurso do método

U ma vertente da tradição marxista adota como critério de filiação a essa linhagem a fidelidade à metodologia de $M$ arx. Este, no entanto, não escreveu nada semelhante a um tratado sobre o método. A questão do método tornou-se assim ponto de litígio. Examinam-se, aqui, pela via do confronto, as exposições metodológicas de Friedrich Engels e G eorg Lukács, adotando por fio suas concepções sobre natureza e história, teoria e prática, bem como suas avaliações acerca das relações entre $\mathrm{M}$ arx e $\mathrm{H}$ egel. Palavras-chave: M étodo; Dialética; M arxismo; M arxismo ocidental.

\section{Abstract}

Dialetics as method working process

A line of the $M$ arxist tradition adopts as an affiliation criterion to it the fidelity to the methodology of $\mathrm{M}$ arx. $\mathrm{He}$, however, never wrote anything similar to a treaty on the method. The question of the method became thus a point of disagreement. $\mathrm{H}$ ere are examined, through confrontation, the methodological expositions of Friedrich Engels and G eorg Lukács, adopting as a line their conceptions on nature and history, theory and practice, as well as their evaluations about the relationship between $\mathrm{M}$ arx and $\mathrm{H}$ egel. Keywords: M ethod; D ialectics; M arxism; Western marxism.

Texto recebido em 11/ 3/2005 e aprovado em $12 / 4 / 2005$.

Ricardo M usse é doutor em Filosofia e professor no D epartamento deSociologia daU SP. E-mail: rmusse@usp. br. 